Юлиян Рамач

UDK 811.161.2(497.11)’373.46

Универзитет у Новим Садзе

Филозофски факултет

Оддзелєнє за русинистику

ramacyu@gmail.com

\title{
РУСКО-СЕРБСКИ ЛЕКСИЧНИ ГОМОНИМИ У РУСКИМ ЯЗИКУ
}

Абстракт: Автор описує руско-сербски лексични гомонимски пари у руским язику як резултат моцного уплїву сербского на руски язик. У бешедним руским язику сербски члени гомонимских парох преовладую над рускима членами. Руски члени парох и руски еквиваленти сербизмох хтори зачувани у бешеди хасную ше и у литературним язику.

Ключни слова: Язик войводянских Руснацох. Уплїв сербского язика на руски. Руско-сербски лексични гомоними у бешедним и литературним язику.

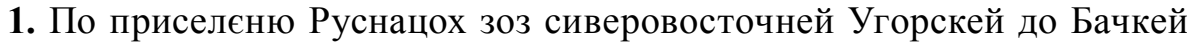
штредком 18. вику, руски язик ше нашол у новим язичним окруженю - сербским, нємецким, мадярским. Наймоцнєйши уплїв по приселєню окончел на ньго сербски (ту подрозумюєме и горватски) язик. Як резултат того уплїву у руским язику ше зявели и велї руско-сербски гомоними. У нашей роботи жадали зме указац яке одношенє у гомонимских парох медзи сербскима пожичками, рускима членами тих парох и рускима еквивалентами сербизмох. Руско-сербски гомоними у руским язику исную на морфологийним, синтаксичним и лексичним уровню. 3 тей нагоди обрабяме лексични гомоними. Лексични пари зме зазначели у Словнїку рускоїо нарояноїо язика (у рукопису), а приклади за нїх з истого словнїка зазначени у записох народней творчосци (В. Гнатюк и др.), у рускей периодики медзи двома войнами 19211941 (виданя Руского народного просвитного дружтва „Просвита” и Культурно-просвитного (-націоналного) союза югославянских Русинов „Заря”), у даєдних новших виданьох як и у руским бешедним язику.

При даєдних застарених руских членох гомонимских парох наводзиме їх карпатски паралели хтори потвердзую же таки руски слова або синтагми дакеди исновали у руским язику.

2.1. Потераз зме зазначели понад 100 пари лексичних руско-сербских гомонимох, алє их ту нє наведземе шицки тримаюци же описани пари достаточно илуструю одношенє медзи рускима и сербскима членами парох 3 
єдного боку и медзи сербскима членами и їх рускима еквивалентами 3 другого боку. Под термином руски ту подрозумюєме слова рускей лексики без огляду на їх походзенє (праславянске, мадярске, нємецке и др.). Под термином сербски подрозумюєме слова сербскей лексики без огляду якого су походзеня у сербским язику.

Медзи зазначенима парами можеме видзелїц два групи.

2.2. У першей групи маме пари у хторих руски член застарени або архаични, а сербизем вошол до руского бешедного и литературного язика. Ту можеме видзелїц два подгрупи.

a) У першей подгрупи обидва члени, руски и сербски, блїзки по значеню або маю заєднїцку семантичну компоненту. Прето сербски члени гомонимских парох можеме похопиц и як калки одн. семантични калки руских членох. Таки пари:

Меновнїки:

p. влада "моц": йокажем им яка у оца небесноїо влаgа (Етн. 29, 69) // сербизем влада “найвисши державни орган” (од серб. влаgа „исте”);

p. закон „общеприлапени шор; вира, правила вири”: А у нїх йаки закон бул: єgен gзень єgен [син] служел оцови, яруіи gзень яруіи служел оцови, а

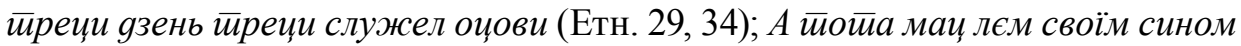
барз наказовала ... gа нє оgсйуйя свой закон божи (Етн. 30, 19-20) // сербизем закон ,акт державней власци” (од серб. закон „исте”);

$p$. племе -ена $c$. „род, фамелия; файта; народ“: Пейров ирраgїgо и иррабаба були нєgобри. Їх син иимж бул нєgобри. Чи йо вифунї ииоио йлеме gакеgи? (приклад з бешеди); Чом ми Руснаци єgно йлеме, єgна вира, ... а ииаріаме ше на gва стирани? (РН 12/1935, 2) // сербизем племе -ена $c$. "родовска заєднїца у рамикох єдного народу” (од серб. йлеме „исте”).

Дїслова:

p. виражиц ше - им ше “видац, виражиц зоз себе гнїв на даким: викричац ше на дакого и под.; зоз справованьом, гестами указац свойо чувства гу

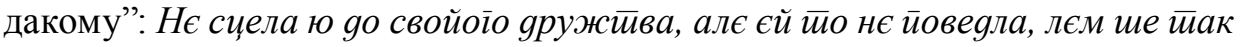
виражела "так ше справовала же єй то дала до знаня" (приклад з бешеди) // сербизем виражиц ше -им ше “зоз словами формуловац свойо думки” (од серб. изразитии се);

p. виявиц -им “виражиц”: йчоли можу зос своїм ілласом виявии раgоси, боль, наїнїваноси и ситрах (РН 14/1935, 4) // сербизем виявиц ,дац вияву” (од серб. изјавиими);

$p$. владац -ам „мац дацо; мочи, буц у стану дацо зробиц”: моgерни сйрави ... йаки gраїи, же ... [менши газдове] их нє влаgаю куйии "не можу их купиц” (РН 5/1928, 2) // сербизем владац -ам “управяц з народом, державу”

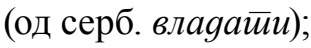


p. заступац -ам $и$ затуповац -пуєм (дакого) ,щициц; бранїц”: [Краль Матяш] вон барз любел хуgобу засйуйовац (Етн. 30, 192) // сербизем заступац

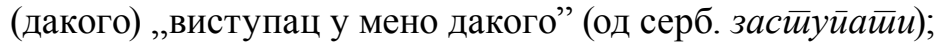

p. наградзиц -им (дакому),,надополнїц дацо дакому”: Мой аренgaш вще ми наїраgзи з gачим кеg gлужей чекам аренgу (приклад з бешеди) // сербизем

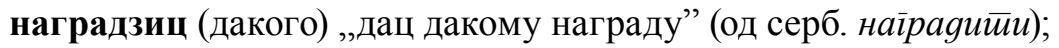

p. наредзиц -им “одредзиц, ушориц; розпоредзиц”: Сушеgово оgйуйовали, а gома маю gва мачки и йса, нє знам коїо нареgзели gа их карми (приклад 3

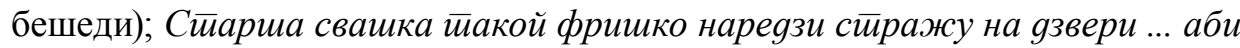
чим скорей легиньох нє йущели (Етн. V, 266) // сербизем наредзиц “розказац”: затио влаgика нареgцель, gа млаgй священикъ ... служи (Цап: Церква, 106) (од серб. нареgити $u$ );

p. погинуц -нєм "умрец, препаднуц; угинуц": [У Русиї] вельо йарасӣох йойинуло og ìлаgy (РН 13/1934, 1) // сербизем погинуц “страциц живот” (од серб. йойинуйu);

Прикметнїки:

$p$. одлични ,хтори ше по дачим видзелює од других, розлични; визнач-

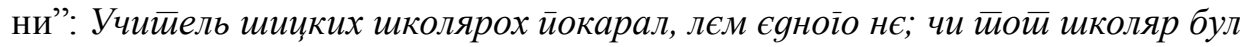
ogлични og gруїuх чи иุo? (приклад з бешеди) // сербизем одлични „найлєп-

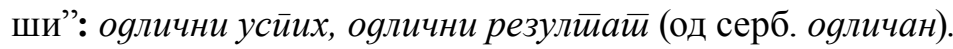

б) У другей подгрупи пари у хторих руски и сербски член цалком розличного значеня, а руски член, як и у предходней групи, застарени або архаични.

Меновнїки:

p. гужва „капча на драбинки коча за хтору заквачена льовч” // сербизем гужва „дрилянє, цисканє” (од серб. іуужва „исте”.

Дїслова:

p. добиц -иєм зак. “з бицом забиц, дотлучиц” (од прасл. biti): Taк ю [ровку] бил ... И з тилм ю gобил (Етн. 30, 5). // сербизем добиц -иєм зак. “достац,

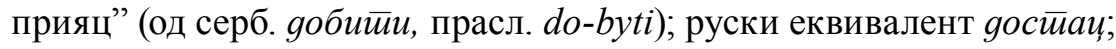

p. запрепасциц -им “знїчтожиц, упрепасциц”: алкоїол икоgзи и зайрейасцел уж езри и езри нашоїо нароgу (РК 1925, 134) // сербизем

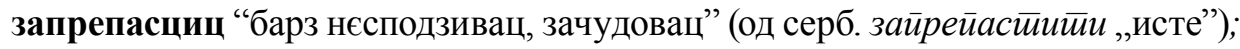

p. намириц -им (на дакого/дацо) "наисц, натрафиц на дакого/дацо" Намири хлайец на єgну колїбу, йам бул єgен юі̄ас з овцами (Етн. 29, 53) // сербизем намириц ,накармиц; виплациц длуство; ушориц дачийо медзисобни рахунки” (од серб. намирийи „исте”); руски еквиваленти накармиц, вийлащчиц и др.;

p. приявиц -и: млєко ,нараз почац давац млєка, почац ше доїц (а пред тим нє мац млєка) (о крави, кози)“ (приклад з бешеди) // сербизем приявиц 
“поднєсц прияву власцом, удац” (од серб. йријавитии „исте“); нашо еквиваленти ygau и йpugau;

p. руковац -куєм “одходзиц до войска" // сербизем руковац "робиц, управяц (з машину и под.)" (од серб. руковатии);

p. утвердзиц ше -им ше „прешвечиц ше“ (слц. utvrdit' sa “исте”): Tegu

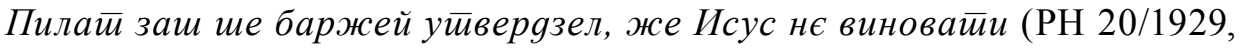
4) // сербизем утвердзиц ше „поставиц утвердзенє коло себе“ (од серб. уйвряитии се);

p. часциц -им “часто ходзиц дагдзе”: Бачи К. часчи у Коиуре, бо маю йу роgзини (приклад з бешеди) (од часйо) // сербизем часциц “госциц; плациц

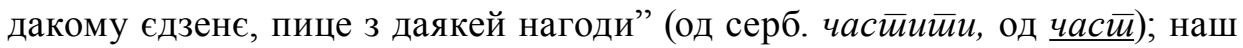
найблїзши еквивалент їосцици.

2.3. У другей групи маме пари у хторих ше обидва члени, руски и сербски, хасную у сучасним язику. Як и у першей групи, и ту можеме видзелїц два подгрупи.

a) У першей подгрупи обидва члени подобного значеня або маю заєднїцку семантичну компоненту, та сербизем можеме тримац за калк одн. семантични калк руского слова. Таки пари:

Меновнїки:

p. брат „син у одношеню гу другим дзецом истих родичох” // сербизем брат „братняк”, лєм у бешедним язику (од серб. брай „исте“); наш еквивалент брайняк;

$p$. розкош $x$. „вельке задовольство, ужиток“ и мн. розкоши “задовольства,

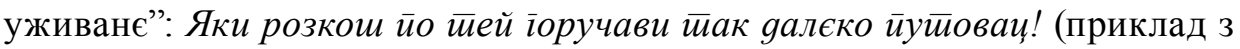
бешеди); Чи ши у розкошох, чи у вельким жалю / же я за кайону у ииим иудзим краю? (ЮРНП, 14) // сербизем розкош $x$. „луксуз” (од серб. раскош „исте”);

$p$. розсоль ж. „слана юшка хтора вишла з насолєного меса; слана вода у хторей ше солї, конзервує месо“: За месо нє ииреба иравиц моцну розсоль, бо соль оє месо (приклад з бешеди) // сербизем розсоль ж. „юшка у квашеней капусти, капусна юха” (од серб. расо „исте”); наш еквивалент вираз кайусна юxa.

p. скора ж. "скора на целу; скора на жеми” // сербизем скора “лупа древа, овоцного плода и под.” (од серб. кора „исте”); наш еквивалент луйа.

Прикметнїки:

p. бесни "нєстримани" // сербизем бесни «барз нагнївани” (од серб. бес$a н$, „исте”); наш найблїзши еквивалент розєgзени;

p. бистри „чисти”: бистира воgа // сербизем бистри „мудри” (од серб. бисйар „исте"); 
p. криви „нє прости, викривени” // сербизем криви „виновати” (од серб.

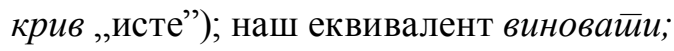

р. лукави „хтори лєм себе грабе” // сербизем лукави „нєщири, гамишни” (од серб. лукав „исте”); наш еквивалент іамишни;

p. погубени ,залапени з ферментацию; нєисправни” // сербизем погубени „готови на подли поступки” (од серб. йокварен „исте”).

Дїслова:

p. бавиц -им (дакого): бавиц gзецко // сербизем бавиц (дацо): бавиц фоябал;

p. бродзиц -им „нє спац вноци, алє дацо робиц”: Keg зме хори, маи ири намей йосиелї ноцами броgзи (шк. сост.) // сербизем бродзиц „блукац, ходзиц” (од серб. броgитии „исте”); нашо еквиваленти хоgзии, йліваи (напр. по морйох), блукаи (ше);

p. виняц -нєм „вжац, вибрац з нукашньосци дачого” // сербизем виняц

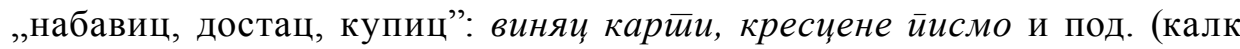
сербского изваgийи „исте”); нашо еквиваленти вименїи, куйии и др.;

p. дзвонӥц -їм „оглашовац ше з дзвонєньом”: gзвонї йолаgнє // сербизем дзвонӥц „бренкац (о телефону и под.)”: gзвонї иелерон, химошка gзвонї на gзверох (од серб. звонити „исте"); наш еквивалент бренкац;

$p$. забавяц ше -ям ше “затримовац ше дагдзе длужей як треба, трациц час”: „Ганьо, я берем канйу йа иязем на ариеейску!” „Добре, льем ше ииам нье забавяйце” (РЗаря 3/1939, 7) // сербизем забавяц ше (з даким) “ходзиц (о легиньови и дзивки)": Вони gвойо ше уж gва роки забавяю (од серб. забављаиии се „исте”); наш еквивалент хоgзии з даким;

p. засушиц ше -им ше "висушиц ше": нєйоgерляна жем ше засушела (PH) // сербизем засушиц ше "престац давац млєко, заяловиц ше (о крави, кози)" (од серб. засушити и и засушитии се „исте“); наш еквивалент заяловии ше;

$p$. каяц ше каєм ше рел. „жаловац пре зробени грих“: Там зме ше мойли нє лєм каяи за свойо ірихи, алє в єgно и йокуйовач за свойо дочасни кари (РН 67/1926, 3) // сербизем каяц ше „бановац” (од серб. кајайи се „исте”); наш еквивалент бановац;

p. погубиц ше -им ше „постац нєисправни; достац хибу, хороту и под.”: Пойубела ше іоозинка; Крава ше иолиубела: нє виртала, а иеераз вирта; Хвиля ше йоіуббела (приклади з бешеди) // погубиц ше „морално ше погубиц” (од

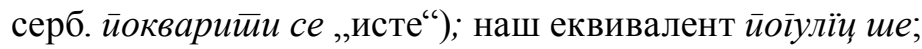

$p$. подруциц -им „покрадзме подложиц, серб. потурити“: Поgруцелї им

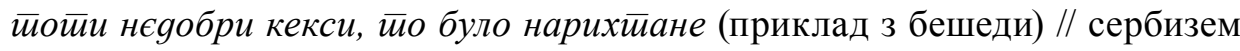
подруциц „нє сполнїц обчекованя”: Кукурица йоїо року йоруцела (од серб. йоgбаиииеи ,исте“); 
p. поздравиц -им (дакого) “послац дакому поздрав”: Дзеции, йозgравиче мачер (приклад з бешеди) // сербизем поздравиц „привитац”: Преgсияайель

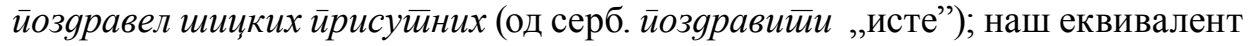
иривитиаи;

р. посцигнуц -нєм “сцигнуц поробиц”: Тельо маме робойи, нє можеме йосииїнуи (приклад з бешеди) // сербизем посцигнуц „витвориц резултат, успих и под." (од серб. иостиићи „исте“);

p. пригвариц -им (нєзак. пригваряц) “прекоментаровац”: увиgзела тиам

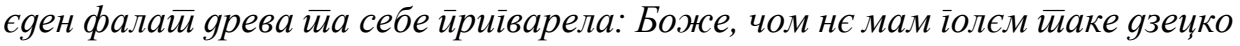

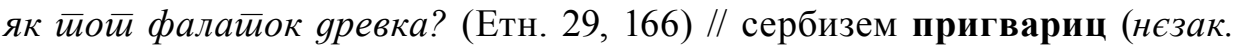
пригваряц) ,виражиц свойо нєзадовольство; указац на нєдостатки” (од серб. йриїоворийи „исте”); руски еквивалент gоїнаи/gоїаняи;

p. уживац -ам „приїмац; хасновац; єсц, пиц” // сербизем уживац „робиц дацо з ужитком” (од серб. уживатии „исте”);

p. уписац -ишем “дакус написац”: Та уйиш сину gайо за новини най ше и я зраяуєм gачому (Жирош: МСМ, 88) // уписац ,записац до даякого списку”: сина gо школи (од серб. уйисайи „исте”); руски еквивалент зайисащ;

$p$. учиц -им „давац знаня дакому”: бо ме [мац] роботии нє учела (нар. писня) // сербизем учиц „звладовац, приїмац нови знаня”: у школи маме вельо учии (од серб. учити „исте”); руски еквивалент учии ше: у школи ше маме вельо учич.

3 наведзених парох велька векшина, и руски и сербски член, хасную ше и у бешедним и у литературним язику. У литературним язику затераз зме

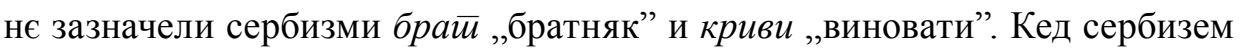
ма руски еквивалент, вон ше у литературним язику хаснує паралелно 303 сербизмом. Таки сербско-руски пари: сербизем скора // рус. луй бесни // рус. розєgзени, сербизем лукави // рус. (ридко) іамишни, сербизем бродзии // рус. хоэзии, иллїваи, блукаи (ше), сербизем gзвонїи (о телефону и под.) // рус. бренкаи, сербизем забявяи ше // рус. хоgзии з gаким, сербизем засушии ше (о крави, кози) // рус. заяловии ше, сербизем каяи ше // рус. бановаи, сербизем йоздравии, „дочекац з привитом” // рус. ирривитиаи, сербизем йриїварии, „указац на хибу” // рус. gоїнаи, сербизем уйисаи (до школи и под.) // рус. зайисаи, сербизем учиц „здобувац нови знаня” // рус. учии ше.

б) У другей подгрупи маме пари у хторих обидва члени цалком розличного значеня.

Меновнїки:

p. брух „нукашньосц цела: жалудок и черева" // сербизем брух „пукнутосц” (од серб. брух „исте”); 
p. лопов „главова косц” // сербизем лопов „крадош”, лєм у бешедним

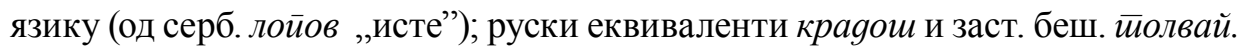

Прикметнїки:

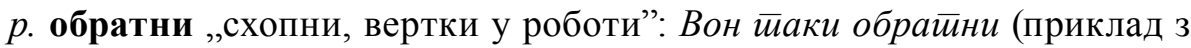
бешеди) // сербизем обратни „наспак обрацени або зробени” (од серб. обра$\bar{u} a н$, „исте“); то и присловнїки $p$. обратно „схопно, вертко” // сербизем обратно „наспак” (од серб. обрайно „исте”); руски еквивалент присловнїк насйак.

Дїєслова:

$p$. важиц -им „мерац (о мажи и под.)”: Мажа gобре важи „добре мера” (приклад з бешеди) // сербизем важиц „мац важносц” (од серб. важсиии „исте");

p. закладац ше -ам ше „обецовац добри резултат”: Кукурица ше gобре заклаga (приклад з бешеди) // сербизем закладац ше "трудзиц ше, намагац

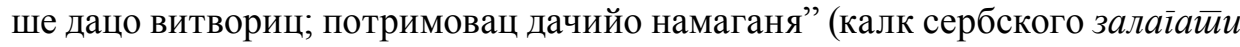
се „исте“"); руски еквиваленти: йилноваи, тируgзиц ше, иси за gачим;

$p$. одказац -ажем (нєзак. одказовац) (дакому $u$ на дакого) „послац порученє": Оgказал на чиковша gа ириженє минеш, gа себе коня вибере (Етн. $29,46)$ // сербизем одказац (нєзак. одказовац) ,розтаргнуц контракт з даким" (од серб. оикказайи „исте”);

р. одлучиц -им (нєзак. одлучовац) „одбиц дзецко або младе од цицаня” // сербизем одлучиц (нєзак. одлучовац) ,ришиц, принєсц одлуку” (од серб. одлучитии ,исте");

$p$. поховац -ам "по одредзеним обряду закопац умартого, серб. сахранити” // сербизем поховац -хуєм кух. „(у)пражиц у витрепаним вайцу, муки и отрошинкох" (од серб. йоховай $и$, „исте“);

p. розправяц -ям “мишаюци готовиц (покарму и под.)” // сербизем розправяц „дискутовац” (од серб. расйрављайи „исте“);

p. хранӥц (ше) -їм (ше) “мерковац, чувац (ше)”: бо сам вас Боі хранї и бранї и за вас ше стиара (РН 14/1933, 4) // сербизем хранїц (ше) “кармиц (ше), костирац (ше)”, лєм у бешедним язику (од серб. хранитии се „исте”); руски еквиваленти костиираи (ше)), кармиц (ше).

Окреме треба спомнуц прикметнїцку и присловнїцку антонимну пару, хтори у руским язику постали гомоними: $p$. спори „швидки, фришки; досц вельки”; всл. spori “исте”: spora robota (Цамбел) // сербизем спори „хтори помали роби” (од серб. сйор „исте“): У стиарих часох ... млєло ше зарно ... на сйорих воgенїцох (= цо помали млєли) (РН 37/33, 1); p. споро „швидко” // сербизем споро „помали”: Газдованє ишло им сйоро (РК 1921, 21) (од серб. сйоро „исте”); руски еквиваленти: вираз хйори йомали роби и присловнїк иомали. 
Векшина з наведзених сербизмох у тей групи хасную ше и у литературним язику. Даєдни з нїх означую даяке нове поняце або нову ниянсу у значеню, за хтору руски язик нє ма одвитуюци еквивалент (брух, важии, оgказаи, йоховач, розиравяи). До литературного язика нє прилапени сербизми лойов (рус. екв. краяош)", сйори (рус. екв. хииори йомали роби, хоgзи и под.), сйоро (рус. екв. иомали), хранйи (ще) (рус. екв. косиираи (ще), кармии (ще)). Сербизем у литературним язику заклаgаи ше ма руски еквиваленти ииилнваи, йрудзии ше, иси за дачим.

3. У тей роботи описани руско-сербски гомонимски пари на лексичним уровню. Медзи коло 50 наведзенима гомонимскима руско-сербскима парами найвецей сербски члени парох (коло 35) представяю калки або семантични калки руских членох тих парох. Векша часц наведзених руских членох ше хаснує у сучасним бешедним и литературним язику. Менша часц руских членох нєшка застарена або архаична. Найвекша часц сербских членох гомонимских парох ше хаснує и у руским бешедним и у сучасним литературним язику. Руски еквиваленти сербских членох, кед же су зачувани у язику, у литературним язику ше хасную паралелно зоз сербизмами, а ридше место сербизмох.

\section{ЖРИДЛА}

Гал.: Východoslovenský slovník, I-II. Zredagoval Ondrej R. Halaga. Košice - Prešov, 2002. Ірам.: Рамач, Ю. (2002). Грамайика рускоїо язика за I, II, III и IV класу гимназиї. Завод за уџбенике и наставна средства Београд, 2002.

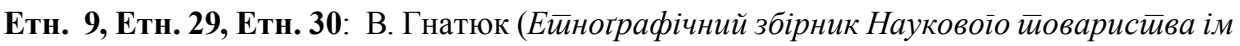
Шевченка - т. 9 (IX): Ейнографічні майеріали з Уїорської Руси, й. ІІІ: Пісні Бач-

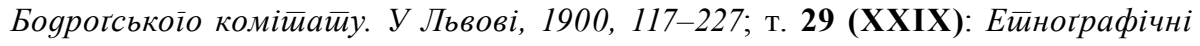
майеріали з Уйорської Руси, й. V, Казки з Бачки. У Львові, 1910; т. 30 (XXX):

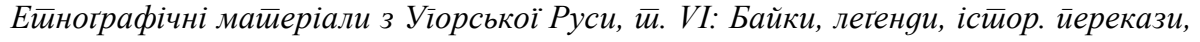
новелї, анекуоши - з Бачки. - УЛьвові, 1911;

Етн. V: Гнатюк, В. (1988). Ейнотрафични майерияли з Уїорскей Руси. Розйрави и сӣайї о Руснацох Бачкей, Сриму и Славониї. Нови Сад: Руске слово.

Жирош: МСМ: Жирош, М. Мили сину мой. НВУ „Руске слово и Грекокатолїцка парохия св. Петра и Павла, Нови Сад, 202;

Кост.: Поезия: Костельник, Г.(1970). Поезия на бачванско-сримским руским литерайурним язику. Нови Сад: Руске слово.

Рамач: Уплїв: Рамач, Ю. (2006) Уплїв сербского язика на руски у деклинациї прикметнїкох, заменовнїкох и меновнїкох. У: Bogdan Horbal, Patricia Krafcik, Elaine Rusinko, red., Carpatho-Rusyns and Their Neighbors. Essays in Honor of Paul Robert Magocsi (Fairfax, Va: Eastern Christian Publications, 365-376.

РЗаря: Русска заря. Орган культурно-націоналного союза югославянских Русинов (1934-1941). Нови Сад. 
РК: Руски календар за юйославяньских Русинох (1921 - 1941). Руски Керестур: Видатель и властитель Руске народне просвитне дружтво, Руски Керестур;

PН: Руски новини за Русинох у Кральовини С. Х. С. (роки 1924-1941). Властитель Руске Народне Просвитне Дружтво, Руски Керестур.

РНК Заря: Русски нароgни каленgар „Заря”. Видатель и властитель: Културно-национални союз Русинов в Югославіи.

РС - Руске слово. Гласнїк по руски. Нови Сад: Руске слово.

Цамбел: Czambel, S. (1906). Slovenská reč a jej miesto v rodine slovanských jazykov (východnoslovenské nárečie). - Turč. sv. Martin.

Цап: Церква: Цап, М. М. (1996): Церква и школа у Коиуре. Прилоги и жридла. Нови Сад: Грекокатолїцка парохия св. Петра и Павла,.

ЮРНП: Южнославяньских Русинох нарояни йиснї. Позберали и ушорели Дюра Биндас и Осиф Костелник. Р. Керестур - Нови Сад, 1927;

SSN: Slovník slovenských nárečí, I-II. Vydavatel'stvo slovenskej akadémie vied, 1994.

\section{ЛИТЕРАТУРА}

Ахманова О. С. (1974). Словарь омонимов русскойо языка. Москва: Издательство „Советская энциклопедия“.

Виноградов В. В. (1977). Избранные тируgы. Лексиколоїия и лексикоїрафия. Москва: Издательство „Наука”.

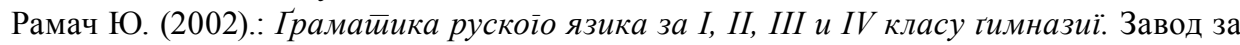
уџбенике и наставна средства Београд,

\section{СКРАЦЕНЯ}

apx. = архаични; беш.= бешедни язик; всл. = восточнословацки; ж. = женски род; зак. = закончени дїєсловни вид; мн. = множина; нар. $=$ народни; нєзак. $=$ нєзакончени дїєсловни вид; поль. = польски; прасл. = праславянски; рсй. = русийски (росийски); рус. = руски (русински); серб. = сербски; с. = штреднї род; слц. = словацки; суч. = сучасни; укр. = українски; х. = хлопски род; чес. $=$ чески; шк. сост. $=$ школярски состав 
Julian Ramač

\section{RUTHENISCH-SERBISCHE HOMONYME IN DER SPRACHE DER RUTHENEN AUS DER VOJVODINA}

\section{ZUSAMMENFASSUNG}

Die Zielsetzung dieser Arbeit ist, das Verhältnis zwischen den serbischen Lehnwörtern im Ruthenischen, ihren ruthenischen Homonympaaren sowie ihren ruthenischen Entsprechungen bei ruthenisch-serbischen Homonymen aufzuzeigen. Die Beispiele stammen aus den aufgezeichneten volkstümlichen Erzählungen (V. Hnaćuk und andere) in der ruthenischen Periodik der Zwischenkriegszeit von 1921 bis 1941 (Ausgaben der Verlage „Prosvita“ und „Zarja“), aber auch aus einigen späteren Ausgaben, dem Manuskript des Wörterbuchs der ruthenischen Volkssprache sowie aus der gesprochenen Sprache.

Ruthenisch-serbische Homonyme sind in der ruthenischen Sprache auf morphologischer Ebene (Genus der Substantive, reflexive/nicht reflexive Verben, Verbstämme, Deklination der Adjektive, Pronomina u. a.) sowie auf syntaktischer Ebene (Präpositionalkonstruktionen, Qualifikationspotential u a.) zu finden. Die meisten Homonympaare existieren jedoch auf lexikalischer Ebene: serbische Lehnwörter sowie Lehnübersetzungen aus dem Serbischen und ihre ruthenischen Paare.

Die aus dem Serbischen stammenden Wörter in den Homonympaaren werden in der gesprochenen Sprache als Teil des ruthenischen Sprachsystems gebraucht. In der Literatursprache werden hingegen auf morphologischer Ebene die ruthenischen Glieder dieser Paare meist anstatt der aus der serbischen Sprache stammenden Wörter verwendet; auf der syntaktische Ebene kommen hingegen die ruthenischen Konstruktionen parallel zu den serbischen Gliedern der Homonympaare zur Anwendung. In den ruthenisch-serbischen Paaren wird auf der lexikalischen Ebene ein Großteil der ruthenischen Glieder in der gesprochenen und geschriebenen Gegenwartssprache verwendet, während ein kleiner Teil heute als veraltet oder archaisch gilt. Die meisten serbischen Glieder der Homonympaare werden in der aktuellen Literatursprache verwendet. Falls sie noch erhalten geblieben sind, werden die ruthenischen Entsprechungen der serbischen Glieder in der Literatursprache parallel zu den serbischen Gliedern verwendet, wobei sie nur selten diese ersetzen.

Schlüsselwörter: Die Sprache der Ruthenen in der Vojvodina. Einfluß der serbischen Sprache auf die Ruthenische. Ruthenisch-serbische lexikalische Homonyme in der gesprochenen ruthenischen Sprache und in der Literatursprache. 